ВЕСТНИК ПНИІУ. ГЕОЛОГИЯ. НЕФТЕГАЗОВОЕ И ГОРНОЕ ДЕЛО

BULLETIN OF PNRPU. GEOLOGY. OIL \& GAS ENGINEERING \& MINING

ISSN 2224-9923

Volume/Toм 15 №18 2016

http://vestnik.pstu.ru/geo/

УДК 622.276

Article / Статья

(C) PNRPU / ПНИПУ, 2016

\title{
EXPRESS ASSESSMENT OF THE INTERACTION BETWEEN THE PRODUCTION AND INJECTION WELLS IN THE TOURNAISIAN-FAMENNIAN DEPOSITS OF OZERNOE FIELD
}

\author{
D.A. Martiushev, P.lu. Iliushin
}

Perm National Research Polytechnic University (29 Komsomolskii av., Perm, 614990, Russian Federation)

\section{ЭКСПРЕСС-ОЦЕНКА ВЗАИМОДЕЙСТВИЯ МЕЖДУ ДОБЫВАЮЩИМИ И НАГНЕТАТЕЛЬНЫМИ СКВАЖИНАМИ НА ТУРНЕ-ФАМЕНСКОЙ ЗАЛЕЖИ ОЗЕРНОГО МЕСТОРОЖДЕНИЯ}

\section{Д.А. Мартюшев, П.Ю. Илюшин}

Пермский национальный исследовательский политехнический университет (614990, Россия, г. Пермь, Комсомольский проспект, 29)

Received / Получена: 24.11.2015. Accepted / Принята: 10.03.2016. Published / Опубликована: 30.03.2016

\section{Key words}

carbonate reservoir, structurally complex deposit, natural fracture, fracture opening, well test, Spearman's rank correlation, Kendall's rank correlation, pressure interference test of formation, lithofacies zones.

\begin{abstract}
The paper discusses Ozernoe oil field, dedicated to the Solikamsk depression and located in the north of the Perm region. Lithofacies of Ozernoe field are divided into four zones: reef slope, lower back reef, upper back reef and bioherm. Efficiency of the implemented flooding system is evaluated according to the level of interaction between the production and injection wells. The elements of math statistics such as Spearman's and Kendall's rank correlation methods are used in order to determine strength and direction of correlation relation between two features. In accordance with these methods, the evaluation of the influence of injection well on production one is carried out based on available field data that include amount of injected and produced water per month for studying wells. Statistical methods based on the calculation of Spearman's and Kendall's rank correlation are not direct methods of evaluation of hydrodynamic connection between wells. In this regard, it is relevant to assess the reliability of its results using conventional methods such as pressure interference test. Noted that the accuracy of statistical methods of Spearman's and Kendall's rank correlation while assessing the level of interaction between the injection and production wells confirmed by pressure interference test. The maximum level of interaction was observed between the wells located within the same lithofacial zone allocated by the method of I.S. Putilov. Express assessment of the interaction between the injection and production wells can be performed using statistical methods of Spearman's and Kendall's rank correlation.
\end{abstract}

Рассматривается Озерное нефтяное месторождение, приуроченное к Соликамской депрессии, расположенное на севере Пермского края, на литолого-фациальной схеме которого выделены зоны: склона рифа, нижнего тылового шлейфа, верхнего тылового шлейфа и биогермного ядра. Оценивается эффективность реализованной системы заводнения, которая определяется как степень взаимодействия между добывающими и нагнетательными скважинами. Используются методы математической статистики - методы ранговой корреляции Спирмена и Кендалла, позволяющие определить силу и направление корреляционной связи между двумя признаками. В соответствии с данными методами оценка влияния работы нагнетательной скважины на добывающую осуществляется на основе имеющегося промыслового материала о месячных объемах закачки воды и отбора жидкости по анализируемым скважинам. Статистические методы, основанные на расчете коэффициентов ранговой корреляции Спирмена и Кендалла, не являются прямыми методами оценки гидродинамической связи между скважинами. В этой связи актуальной представляется оценка достоверности результатов их использования с помощью общепринятых методов, таких как гидропрослушивание. Отмечено, что достоверность применения статистических методов ранговой корреляции Спирмена и Кендалла при оценке степени взаимодействия между нагнетательными и добывающими скважинами подтверждена данными гидропрослушивания. Максимальная степень взаимодействия отмечается между скважинами, расположенными в пределах одной и той же литологофациальной зоны, выделенной по И.С. Путилову. Также отметим, что экспресс-оценка взаимодействия между нагнетательными и добывающими скважинами может быть выполнена с использованием статистических методов ранговой корреляции Спирмена и Кендалла.

\footnotetext{
Dmitrii A. Martiushev (Author ID in Scopus: 56308102400) - postgraduate student at the Department of Oil and Gas Technologies (mob. tel.: +077 951 922 79 88, e-mail: martyushevd@inbox.ru). The contact person for correspondence.

Pavel Iu. Iliushin (Author ID in Scopus: 52563735500 ) - PhD in Engineering, Associate Professor at the Department of Oil and Gas Technologies (mob. tel.: +077 9194884444 , e-mail: ilushin-pavel@yandex.ru).

Мартюшев Дмитрий Александрович - аспирант кафедры нефтегазовых технологий (моб. тел.: +077 951 922 79 88, e-mail: martyushevd@inbox.ru). Контактное лицо для переписки.

Илюшин Павел Юрьевич - кандидат технических наук, доцент кафедры нефтегазовых технологий (моб. тел.: +077 9194884444 , e-mail: ilushin-раvel@yandex.ru).
} 


\section{Introduction}

Ozernoe oil field is dedicated to the Solikamsk depression and located in the north of Perm region. An operator is LUKOIL-PERM LLC. Oil reserves are assigned to the Upper Visean-Bashkirian and Upper Devonian-Tournaisian carbonate complexes.

Oil deposits in the Upper Devonian-Tournaisian (Fransian (Fr), Famennian (Fm) and Tournaisian (T) deposits) are the main in terms of number of dedicated geological reserves. Tournaisian and Famennian are the most representative out of three united to the deposits. Upper Devonian-Tournaisian complex is formed in sharply differentiated sedimentation during formation of Kama-Kinel deflection system, which is the major cause of significant complexity of internal structure and variability of reservoir properties. The reservoir properties are associated with structural facies zones.

The results of analysis of core from TournaisianFamennian deposits on the territory of interests are summarized by A.P. Vilesov [1]. As a result of summary, the scheme of lithofacies zonation including reef crest (RC), inner reef (IR) and outer reef
(OR) was proposed. Later in [2] data from the core study were complexed with data from 3D-seismic using the method of stepwise linear discriminant analysis. Litho-facies scheme was adjusted with following zones: reef slope (RS), lower back reef (LBR), upper back reef (UBR) and bioherm (B). Comparison of lithofacial schemes considered by [1] and [2] is shown on Fig. 1.

Research of fracture and spatial distribution of different types of reservoirs on the deposits of interest [3-5], revealed that lithofacial zonation made by I.S. Putilov correlate with field data, in particular with well test interpretation. Authors found that in lithofacies of upper back reef and adjoined areas crack-porous type of reservoir is dominant. The rest of reservoir is porous. These findings confirm the assumption of considerable complexity of structure. It is obvious that, recovery becomes more complex in such conditions and reservoir pressure maintenance in particular. It is known that displacement of oil by water from pore channels and crack-matrix system occurs under variety of hydrodynamic principles [6-8]. In this regard, study of waterflooding features complex deposits presented by reservoirs of different void types is relevant.

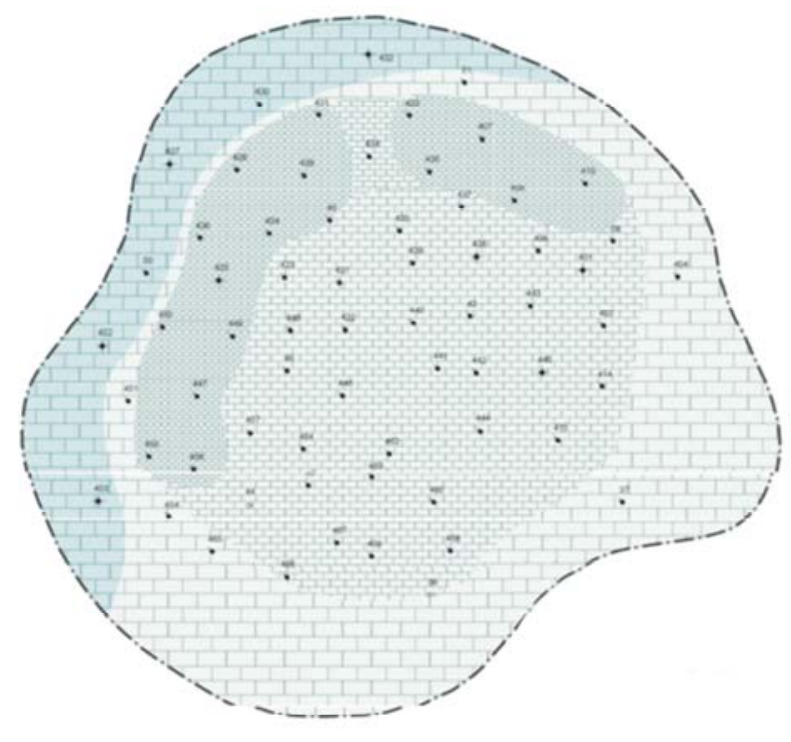

Facies - reef crest

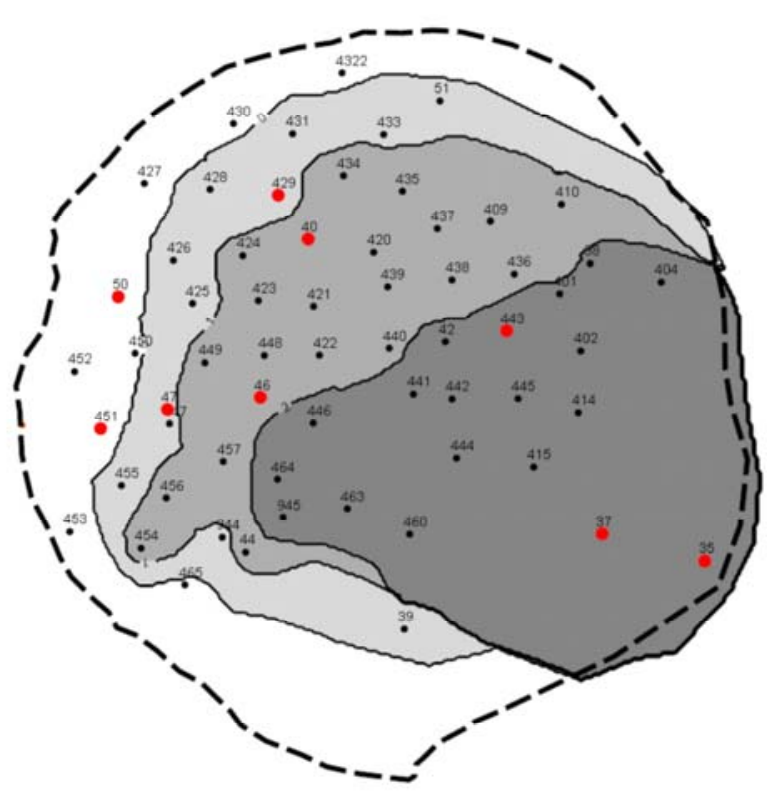

Facies - reef slope

Famennian deposits

Tournaisian deposits

Fig. 1. Comparison of lithofacial schemes of Tournaisian-Famennian deposits of Ozernoe field 


\section{Evaluation of hydrodynamic link between producer and injector with use of statistical methods}

One of the indicators for evaluation of efficiency of implemented flooding system is a level of interaction between producer and injector. There are different ways to evaluate interaction between producers and injectors in reservoir pressure maintenance system, such as tracer studies and interference test. However, they are expensive and unsuitable for express-assessment of interaction between producer and injector.

In such circumstances, be regarded as relevant statistical methods, such as Spearman's and Kendall's rank correlations [9-10], allowing to determine strength and direction of correlation between the two sign. According to these methods diagnosing the injection well influence on production is carried out on the basis of available field data of monthly volume of water injected and liquid produced from the wells of interest.

Spearman's rank correlation coefficient is nonparametric method used to study statistical relationship between phenomena. In this case, level of parallelism between two quantitative rows of studied signs is determined and strength of this relationship is given based on quantitative coefficient. The values of each sign is ranked according to the level of increase (from 1 to $n$ ), then the difference between the ranks $(d)$ corresponding to one observation is determined. Sign $X$ is well injectability, $\mathrm{m}^{3} /$ day, factor $Y$ is well production, tons/day. For sign $X$ and factor $Y$ there are grades assigned. The sequence and results of calculating of Spearman's rank correlation coefficients are considered by the example of wells located in northwestern part of the field and representing a certain element of implemented system development: injection wells № 452 and 453; production wells № 451, 454 and 455 (Fig. 2).

Table 1 below presents data and calculated Spearman's rank correlation coefficient for the pair of wells 453-455 located on a dedicated section of the deposit.
Spearman's rank correlation coefficient is calculated according to the formula

$$
p=1-6 \frac{\sum d^{2}}{n^{3}-n}=1-6 \frac{424,5}{13^{3}-13}=-0,166
$$

Spearman's rank correlation coefficients between wells № 453 and 454 (0.221) and between the wells № 451 and $452(l=0,683)$ are calculated in the same way.

Ranges of possible numerical values of Spearman's rank correlation coefficient and the corresponding strength characteristics are presented in Table 2.

Table 2 shows almost none hydrodynamic link between the wells № 453 and 455; weak strength between wells № 453 and 454 and medium strength between wells № 451 and 452 .

According to [11], the value of Spearman's rank correlation coefficient is often underestimated. In this regard, the results of calculations must be checked using the method of Kendall's rank correlation. Presence of link between wells has to be diagnosed on the basis of the two statistical methods.

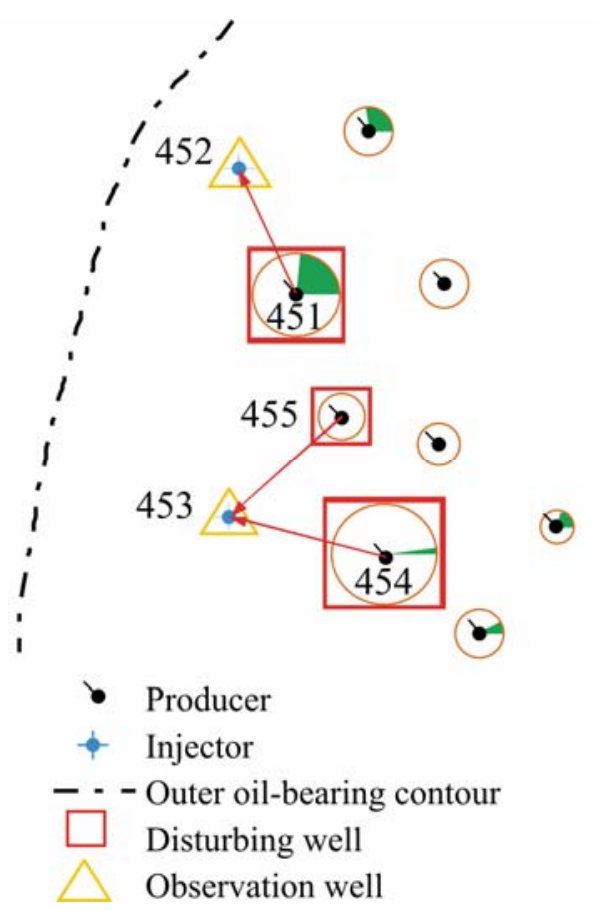

Fig. 2. Deposit section to study interaction between the wells 
Table 1

For calculation of Spearman's rank correlation coefficient

\begin{tabular}{|c|c|c|c|c|c|}
\hline$n$ & $X$ & Y & $\begin{array}{l}\text { Rank } \\
X, d_{x}\end{array}$ & $\begin{array}{l}\text { Rank } \\
Y, d_{y}\end{array}$ & $\left(d_{x}-d_{y}\right)^{2}$ \\
\hline 1 & 22 & 5,677 & 1,5 & 4 & 6,25 \\
\hline 2 & 22 & 5,733 & 1,5 & 5 & 12,25 \\
\hline 3 & 125 & 5,806 & 5 & 8 & 9 \\
\hline 4 & 180 & 5,345 & 10 & 3 & 49 \\
\hline 5 & 140 & 5,763 & 6 & 6 & 0 \\
\hline 6 & 152 & 5,823 & 7 & 9 & 4 \\
\hline 7 & 123 & 6,004 & 4 & 11 & 49 \\
\hline 8 & 175 & 5,771 & 9 & 7 & 4 \\
\hline 9 & 168 & 6,013 & 8 & 12 & 16 \\
\hline 10 & 119 & 5,991 & 3 & 10 & 49 \\
\hline 11 & 197 & 6,093 & 12 & 13 & 1 \\
\hline 12 & 201 & 4,426 & 13 & 1 & 144 \\
\hline 13 & 188 & 5,229 & 11 & 2 & 81 \\
\hline
\end{tabular}

Table 2 As a result, use of the formulas lead to P equals 30

Strength of the link between different values of Spearman's rank correlation coefficients

\begin{tabular}{|c|c|}
\hline $\begin{array}{c}\text { Correlation } \\
\text { coefficient }\end{array}$ & $\begin{array}{c}\text { Characterization } \\
\text { of link strength }\end{array}$ \\
\hline$r_{s}<0,1$ & Hardly exist link \\
\hline $0,101<r_{s}<0,3$ & Weak link \\
\hline $0,301<r_{s}<0,5$ & Moderate link \\
\hline $0,501<r_{s}<0,7$ & Link of medium strength \\
\hline $0,701<r_{s}<0,9$ & Strong strength \\
\hline $0,901<r_{s}<1,0$ & Very strong strength \\
\hline
\end{tabular}

Kendall's rank correlation method is used to determine relationship between the two variables of rank. Kendall's rank correlation coefficient $(\tau)$ is defined as a difference between the probability of coincidence and inversion in these ranks. The calculation of Kendall's rank correlation coefficient made on the example of selected section of deposits are presented below.

Assign grades to the sign $Y$ and factor $X$. Locate the objects so that the ranks of the $X$ provide a natural row. Since the values assigned to each pair of the series are positive, the value " +1 " included in $P$ will be generated only by pairs, which form direct order of $Y$. In the series $Y$ right to the 3 there are 10 ranks, exceeding 3 thus 3 generates $P$ in 10 . To the right of 9 there are 4 grades, exceeding 9 $(13,11,12,10)$, meaning that 4 will be into $\mathrm{P}$ etc.
(Table 3).

Kendall's rank correlation coefficient can be calculated using exact (1) and simplified (2) formulas:

$$
\begin{gathered}
\tau=\frac{P-Q}{\frac{1}{2} N(N-1)}=\frac{35-43}{\frac{1}{2} 13(13-1)}=-0,1, \\
\tau=\frac{4 P}{N(N-1)}-1=\frac{4 \cdot 35}{13(13-1)}-1=-0,1 .
\end{gathered}
$$

Table 3

For calculation of Kendall's rank correlation coefficient

\begin{tabular}{|c|c|c|c|c|c|}
\hline$X$ & $Y$ & $\begin{array}{c}\text { Rank } \\
X, d_{x}\end{array}$ & $\begin{array}{c}\text { Rank } \\
Y, d_{y}\end{array}$ & $P$ & $Q$ \\
\hline 22 & 5,677 & 1 & 4 & 9 & 3 \\
\hline 22 & 5,733 & 2 & 5 & 8 & 3 \\
\hline 125 & 5,806 & 3 & 10 & 3 & 7 \\
\hline 180 & 5,345 & 4 & 11 & 2 & 7 \\
\hline 140 & 5,763 & 5 & 8 & 3 & 5 \\
\hline 152 & 5,823 & 6 & 6 & 4 & 3 \\
\hline 123 & 6,004 & 7 & 9 & 2 & 4 \\
\hline 175 & 5,771 & 8 & 12 & 1 & 4 \\
\hline 168 & 6,013 & 9 & 7 & 1 & 3 \\
\hline 119 & 5,991 & 10 & 3 & 1 & 2 \\
\hline 197 & 6,093 & 11 & 2 & 1 & 1 \\
\hline 201 & 4,426 & 12 & 13 & 0 & 1 \\
\hline 188 & 5,229 & 13 & 1 & 0 & 0 \\
\hline \multicolumn{7}{|r|}{} & & 35 & 43 \\
\hline
\end{tabular}


In order to check the null hypothesis of the equality to null of general Kendall's rank correlation coefficient with competing hypotheses $H_{1}: \tau \neq 0$, with $\alpha$ level of significance critical point has to be calculated:

$$
\mathrm{T}_{\mathrm{cr}}=z_{\mathrm{cr}} \sqrt{\frac{2(2 n+5)}{9 n(n-1)}},
$$

where $n$ is volume recovery; $z_{\text {cr }}$ is critical point of double side area that is defined by Laplace function table.

If $\tau<\mathrm{T}_{\text {cr }}$ means there is no reason to reject the null hypothesis. Rank correlation link between qualitative characteristics is insignificant. If $\tau>T_{\text {cr }}$ then a null hypothesis has to be rejected. Between qualitative characteristics there is significant rank correlation link.

The critical point $z_{\text {cr }}$ is found as:

$$
\Phi\left(z_{\mathrm{cr}}\right)=\frac{1-\alpha}{2}=\frac{1-0,05}{2}=0,475
$$

From Laplace table $z_{\mathrm{cr}}=1,96$.

The value of critical point:

$$
\mathrm{T}_{\mathrm{cr}}=1,96 \sqrt{\frac{2(213+5)}{9 \cdot 13(13-1)}}=0,41 .
$$

Since the condition $\tau<\mathrm{T}_{\text {cr }}$ accepts the null hypothesis rank correlation link between the parameters is not significant.

Thus, both the statistical methods used to evaluate the hydrodynamic link between the injection well № 453 and production well № 454, demonstrate its actual absence.

The other two pairs of selected reservoir area Kendall's method confirm method of Spearman.

\section{Evaluation of authenticity of Spearman's and Kendall's statistical methods of rank correlation application}

Statistical methods based on the calculation of Spearman's and Kendall's rank correlation coeffi- cients are not direct methods to estimate hydrodynamic link between wells. In this regard, it is relevant to assess authenticity of its results using conventional methods such as interference test (IT).

It is known that interference test is studying of the propagation of elastic pulse (disturbances) in reservoir between wells. On this purpose, one of the wells, called disturbing well, change performance mode - it may be well shut, its switch on production with constant flow rate or bottom hole pressure and flow rate change. After the pulse was trigged pressure change is observed in the neighbor wells. It is obvious that the change in pressure in observation wells is caused by both the impulse in disturbing well and reservoir parameters in the direction of each observation wells.

LUKOIL-PERM LLC performs interference test regularly on the fields with complex geological structure, including Ozernoe. An example of hydrodynamic link assessment by interference test on the section of Tournaisian-Famennian deposits, represented by three wells is presented below (see Fig. 2).

Interference test was applied to the north-west part of deposits. During the test wells № 451, 454 and 455 were disturbing wells, № 452 and 453 were observation wells. The regimes of surrounding wells were stabilized to improve result authenticity. Example of obtained in research interference curve showing the change in pressure in observation well, is presented on Fig. 3.

The processing of interference test was carried by graphoanalitical method (integral). The method represents analytical processing of experimental response of curves. According to analytically found relationships the charts with straight lines were plotted. From the slope of these lines to the horizontal axis and the intercept on the y-axis, formation properties are defined. Obtained interference curves were processed by this method. Processing results are presented in Table 4. To assess reliably of reservoir parameters from processed interference curves the results of interpretation of build-up and drawdown curves are presented in table 4 [12-16].

Presented in the Table 4 data shows permeability obtained by interference test around wells № 453-454 


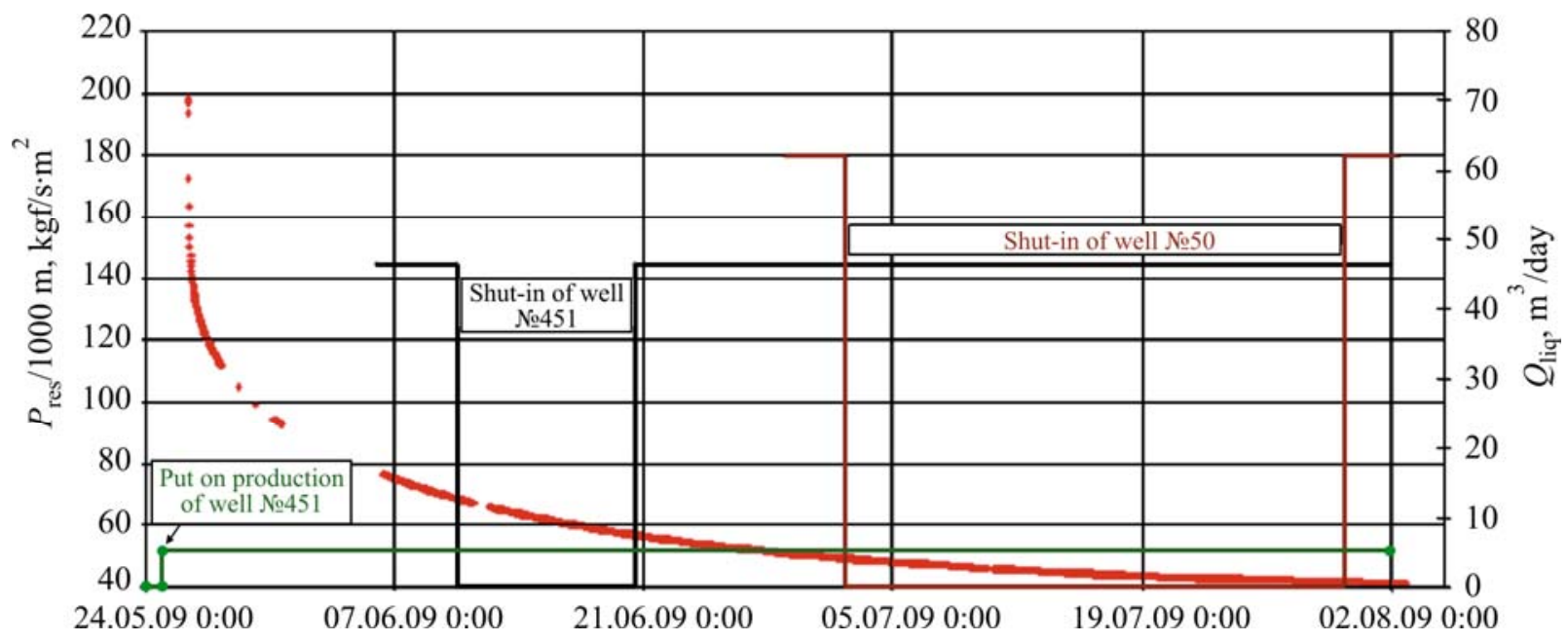

Fig. 3. Curve of pressure change in observation well № 453

Table 4

Results of well test data processing

\begin{tabular}{|c|c|c|c|c|}
\hline Well № & Test type & $\begin{array}{c}\text { Piezo- } \\
\text { conductivity, } \\
\mathrm{m}^{2} / \mathrm{s}\end{array}$ & $\begin{array}{c}\text { Hydraulic } \\
\text { conductivity, } \\
\mathrm{mcm}^{2} \cdot \mathrm{cm} / \\
\mathrm{mPa}^{\prime} \mathrm{s}\end{array}$ & $\begin{array}{c}\text { Permeability, } \\
\mathrm{mD}\end{array}$ \\
\hline 453 & $\begin{array}{c}\text { Drawdown } \\
\text { curve }\end{array}$ & 0,29 & 26,3 & 14,8 \\
\hline 454 & $\begin{array}{c}\text { Build-up } \\
\text { curve }\end{array}$ & 0,07 & 5,8 & 1,4 \\
\hline 455 & $\begin{array}{c}\text { Build-up } \\
\text { curve }\end{array}$ & 0,92 & 84,4 & 18,9 \\
\hline $453-454$ & Interference & 0,27 & 1,3 & 7,2 \\
\hline $453-455$ & Interference & 0,69 & 14,8 & 17,2 \\
\hline $451-452$ & Interference & 1,08 & 162,4 & 75,4 \\
\hline
\end{tabular}

of $7.2 \mathrm{mD}$ is in a range of permeability values defined by drawdown and build-up curves (14.8 and 1.4 respectively). A similar situation is observed for a pair of wells № 453-455. Compliance of permeability values, defined by interpretation of the interference to the values determined by pressure buildup (drawdown) is a factor that confirms authenticity of interference test.

The existence of hydrodynamic link between the wells and its intensity were measured by the piezoconductivity coefficient. Analysis of this parameter shows that the level of interaction between the wells № 451 and 452 has to be considered as maximal for the sector of interest. Besides, wells hardly communicate. These conclusions are coherent with calculation results obtained by Spearman's and Kendall's statistical method of rank correlation.
Thus, the data analysis of interference test conducted on the north-western part of the TournaisianFamennian deposits of Ozernoe field confirm authenticity of calculations of the link between wells by Spearman's and Kendall's rank correlation which leads to the possibility of their use for express solution of this task.

\section{Evaluation of interaction between all the wells of deposit with use of statistical methods of rank correlation}

Proven by interference test authenticity statistical methods, based on calculations of Spearman's and Kendall's rank correlation coefficients allows to estimate the level of interaction between the wells on entire reservoir area and not only in the areas covered by the research.

For all pairs of wells of Tournaisian-Famennian deposits of Ozernoe field Spearman's rank correlation coefficients (confirmed by Kendall) were calculated and used for estimation of interaction between the wells. The calculation results are combined with lithofacial diagrams and graphically presented in Fig. 4.

Data presented in Fig. 4 allow selecting reservoir areas with maximal and minimal influence of applied pressure maintenance system on performance of neighbor wells. Wherein, combination of results with lithofacial scheme according to I.S. Putilov allows to say that the maximal interaction between injection 


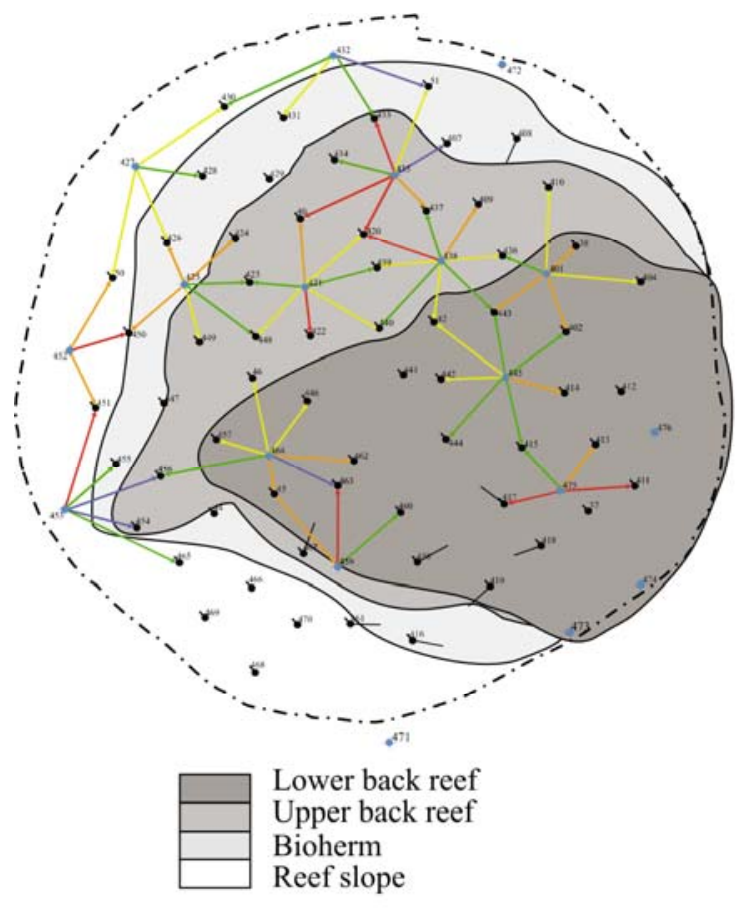

$a$

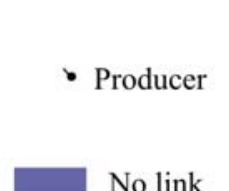

Map key symbols:

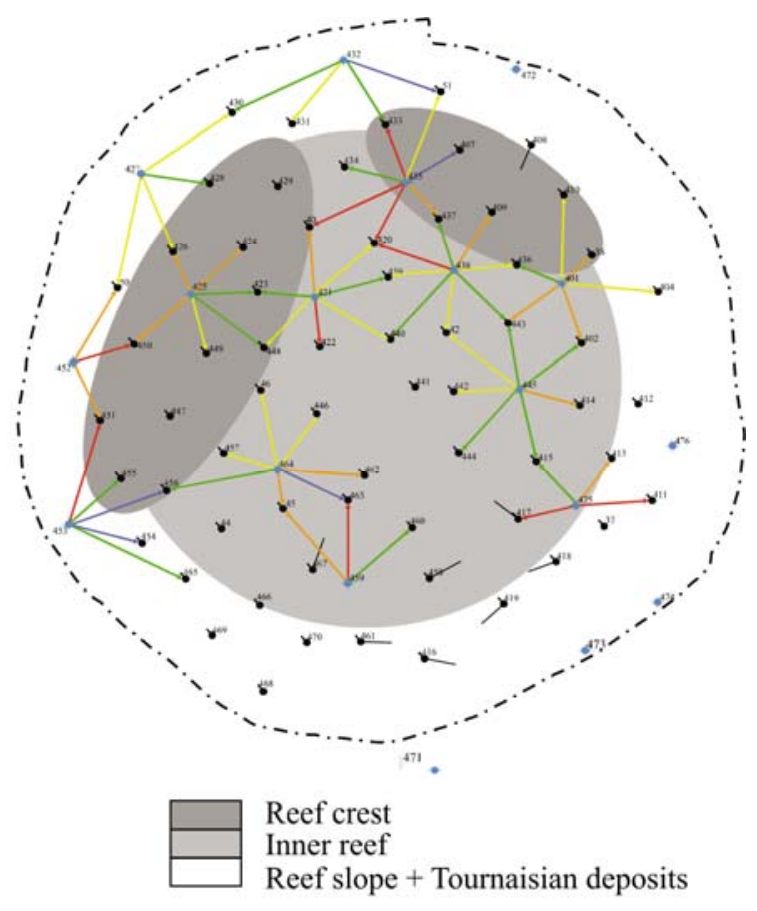

$b$

$$
\begin{aligned}
& \text { Map key symbols: } \\
& + \text { Injector }- \text { Producer with horizontal section } \quad-\cdot-\cdot \text { Outer oil-bearing contour } \\
& \text { Spearman's rank correlation coefficient }
\end{aligned}
$$

Fig. 4. Scheme of well interaction combined with lithofacial zonation: $a$ - according to I.S. Putilov; $b$ - according to A.P. Vilesov

and production wells is observed in their placement within the same lithofacial zone. The interaction between the zones is minimal. At first this conclusion has a practical benefit in terms of corrections of current development scheme. At second, it confirms lithofacies analysis authenticity based on results of integration of core study data and 3D-seismic.

\section{Conclusions}

1. Express-assessment of the interaction between producers and injectors can be performed

\section{References}

1. Vilesov A.P. Raznoobrazie tipov treshchinovatosti v verkhnedevonskikh organogennykh postroikakh Bereznikovskoi karbonatnoi platformy (Permskii krai) [Fracturing diversity in the Upper-Devonian organogenic structures of the Bereznikovskaya carbonate platform (Perm region)]. Rify i karbonatnye psefitolity: materialy vserossiiskogo litologicheskogo soveshchaniia. Syktyvkar: Geoprint, 2010, pp. 45-47. with use of Spearman's and Kendall's rank correlation methods.

2. The authenticity of statistical methods of Spearman's and Kendall's rank correlation in the assessment of the level of interaction between the injection and production wells confirmed by interference test (on example of Tournaisian-Famennian deposits of Ozernoe deposits).

3. Maximal level of interaction is observed between the wells located in the same lithofacial zone, allocated according to the I.S. Putilov.

\section{Список литературы}

1. Вилесов А.П. Разнообразие типов трещиноватости в верхнедевонских органогенных постройках Березниковской карбонатной платформы (Пермский край) // Рифы и карбонатные псефитолиты: материалы всероссийского литологического совещания. - Сыктывкар: Геопринт, 2010. C. $45-47$. 
2. Putilov I.S. Razrabotka tekhnologii kompleksnogo izucheniia geologicheskogo stroeniia i razmeshcheniia mestorozhdenii nefti i gaza [Development of technologies for a comprehensive study of the geological structure and location of oil and gas fields]. Perm': Izdatel'stvovo Permskogo natsional'nogo issledovatel'skogo politekhnicheskogo universitetata, 2014. $285 \mathrm{p}$.

3. Cherepanov S.S. Kompleksnoe izuchenie treshchinovatosti karbonatnykh zalezhei metodom Uorrena-Ruta $\mathrm{s}$ ispol'zovaniem dannykh seismofatsial'nogo analiza (na primere turne-famenskoi zalezhi Ozernogo mestorozhdeniia) [Integrated research of carbonate reservoir fracturing by Warren-Root method using seismic facies analysis (evidence from Tournaisian-Famennian deposit of Ozernoe field)]. Bulletin of PNRPU. Geology. Oil \& Gas Engineering \& Mining, 2015, no. 14, pp. 6-12. DOI: 10.15593/2224-9923/2015.14.1.

4. Galkin V.I., Ponomareva I.N., Cherepanov S.S. Razrabotka metodiki otsenki vozmozhntstei vydeleniia tipov kollektorov po dannym krivykh vosstanovleniia davleniia po geologo-promyslovym kharakteristikam plasta [Development of the methodology for evaluation of possibilities to determine reservoir types based on pressure build-up curves, geological and reservoir properties of formation (case study of Famen deposits of Ozernoe field)]. Bulletin of PNRPU. Geology. Oil \& Gas Engineering \& Mining, 2015, no. 17, pp. 32-40. DOI: $10.15593 / 2224-9923 / 2015.17 .4$.

5. Cherepanov S.S., Ponomareva I.N., Erofeev A.A., Galkin S.V. Opredelenie parametrov treshchinovatosti porod na osnove kompleksnogo analiza dannykh izucheniia kerna, gidrodinamicheskikh i geofizicheskikh issledovanii skvazhin [Determination of rock fracture parameters on the basis of a comprehensive analysis of the core study data, hydrodynamic and geophysical well survey]. Neftyanoe Khozyaistvo - Oil Industry, 2014, no. 2, pp. 94-96.

6. Golf-Rakht T.D. Osnovy neftepromyslovoi geologii i razrabotki treshchinovatykh kollektorov [Fundamentals of fractured reservoir engineering]. Moscow: Nedra, 1986. 608 p.

7. Khanna A., Neto L.B., Kotousov A. Effect of residual opening on the inflow performance of a hydraulic fracture. International Journal of Engineering Science, 2014, no. 74, pp. 80-90. DOI: 10.1016/j.ijengsci.2013.08.012.

8. Bortolan Neto L., Kotousov A. Residual opening of hydraulic fractures filled with compressible proppant. International Journal of Rock Mechanics and Mining Sciences, 2013, no. 61, pp. 223-230. DOI: 10.1016/j.jirmms.2013.02.012.

9. Blagoveshchenskii Iu.N. Tainy korreliatsionnykh sviazei v statistike: monografiia [Secrets of the correlations in the statistics: a monograph]. Moscow: Nauchnaia kniga: INFRA-m, 2009. 158 p.

10. Dorodnitsyn V.A. Gruppovye svoistva raznostnykh uravnenii [Group properties of difference equations]. Moscow: Fizmatlit, 2001. 236 p.

11. Mirzadzhanzade A.Kh. Tekhnologiia i tekhnika dobychi nefti [Technology and equipment of oil production]. Moscow: Nedra, 1986. 385 p.

12. Djebbar T., Erle C. Donaldson petrophysics: Theory and practice of measuring reservoir rock and fluid transport properties. 2nd ed. Elsevier, 2004. 889 p.

13. Ponomareva I.N. K obrabotke krivykh vosstanovleniia davleniia nizkoproduktivnykh skvazhin [To the processing of pressure build-up curves of low productivity wells]. Neftyanoe Khozyaistvo - Oil Industry, 2010, no. 6, pp.78-79.
2. Путилов И.С. Разработка технологий комплексного изучения геологического строения и размещения месторождений нефти и газа. - Пермь: Изд-во Перм. нац. исслед. политехн. ун-та, 2014. - 285 с.

3. Черепанов С.С. Комплексное изучение трещиноватости карбонатных залежей методом Уоррена-Рута с использованием данных сейсмофациального анализа (на примере турне-фаменской залежи Озерного месторождения) // Вестник Пермского национального исследовательского политехнического университета. Геология. Нефтегазовое и горное дело. - 2015. - № 14. - С. 6-12. DOI: 10.15593/2224$9923 / 2015.14 .1$

4. Галкин В.И., Пономарева И.Н., Черепанов С.С. Разработка методики оценки возможностей выделения типов коллекторов по данным кривых восстановления давления по геолого-промысловым характеристикам пласта // Вестник Пермского национального исследовательского политехнического университета. Геология, нефтегазовое и горное дело. - 2015. № 17. - С. 32-40. DOI: 10.15593/2224-9923/2015.17.4

5. Определение параметров трещиноватости пород на основе комплексного анализа данных изучения керна, гидродинамических и геофизических исследований скважин / С.С. Черепанов, И.Н. Пономарева, А.А. Ерофеев, С.В. Галкин // Нефтяное хозяйство. - 2014. - № 2. - С. 94-96.

6. Голф-Рахт Т.Д. Основы нефтепромысловой геологии и разработки трещиноватых коллекторов. - М.: Недра, 1986. $608 \mathrm{c}$.

7. Khanna A., Neto L.B., Kotousov A. Effect of residual opening on the inflow performance of a hydraulic fracture // International Journal of Engineering Science. - 2014. - № 74. - P. 80-90. DOI: 10.1016/j.ijengsci.2013.08.012.

8. Bortolan Neto L., Kotousov A. Residual opening of hydraulic fractures filled with compressible proppant // International Journal of Rock Mechanics and Mining Sciences. - 2013. - № 61. P. 223-230. DOI: 10.1016/j.jirmms.2013.02.012.

9. Благовещенский Ю.Н. Тайны корреляционных связей в статистике: монография. - М.: Научная книга: ИНФРА-м, 2009. - $158 \mathrm{c}$.

10. Дородницын В.А. Групповые свойства разностных уравнений. - М.: Физматлит, 2001. - $236 \mathrm{c}$

11. Мирзаджанзаде А.Х. Технология и техника добычи нефти. - М.: Недра, 1986. - 385 с.

12. Djebbar T., Erle C. Donaldson petrophysics: Theory and practice of measuring reservoir rock and fluid transport properties. 2nd ed. - Elsevier, 2004. - P. 889.

13. Пономарева И.Н. К обработке кривых восстановления давления низкопродуктивных скважин // Нефтяное хозяйство.2010. - № 6. - С. 78-79.

14. Ерофеев А.А., Пономарева И.Н., Мордвинов В.А. К определению пластового давления при гидродинамических исследованиях скважин в карбонатных коллекторах // Нефтяное хозяйство. -2011 . - № 4. - С. 98-100.

15. Amanat U. Chaudry. Oil well testing handbook / Advanced TWPSON Petroleum Systems Inc. - Houston, 2004. - 525 p.

16. Earlougher R.C., Jr. Advances in well test analysis / Society of Petroleum Engineers of AIME. - New York, 1977. $-264 \mathrm{p}$. 
14. Erofeev A.A., Ponomareva I.N., Mordvinov V.A. K opredeleniiu plastovogo davleniia pri gidrodinamicheskikh issledovaniiakh skvazhin v karbonatnykh kolletkorakh [To the determination of reservoir pressure while well test in carbonate reservoirs]. Neftyanoe Khozyaistvo - Oil Industry, 2011, no. 4, pp. 98-100.

15. Amanat U. Chaudry. Oil well testing handbook. Advanced TWPSON Petroleum Systems Inc. Houston, 2004. 525 p.

16. Earlougher R.C., Jr. Advances in well test analysis. Society of Petroleum Engineers of AIME. New York, 1977. 264 p.

Please cite this article in English as:

Martiushev D.A., Iliushin P.Iu. Express assessment of the interaction between the production and injection wells in the TournaisianFamennian deposits of Ozernoe field. Bulletin of PNRPU. Geology. Oil \& Gas Engineering \& Mining, 2016, vol.15, no.18, pp. 33-41. DOI: $10.15593 / 2224-9923 / 2016.18 .4$

Просьба ссылаться на эту статью в русскоязычных источниках следующим образом:

Мартюшев Д.А., Илюшин П.Ю. Экспресс-оценка взаимодействия между добывающими и нагнетательными скважинами на турнефаменской залежи Озерного месторождения // Вестник Пермского национального исследовательского политехнического университета. Геология. Нефтегазовое и горное дело. - 2016. - Т.15, №18. - С. 33-41. DOI: 10.15593/2224-9923/2016.18.4 